\title{
Distribution of the timber quality attribute 'knot surface' in logs of Fagus sylvatica L. from pure and mixed forest stands
}

\author{
Kirsten Höwler ${ }^{1}$ (D) $\cdot$ Torsten Vor $^{1} \cdot$ Peter Schall ${ }^{1} \cdot$ Peter Annighöfer $^{2} \cdot$ Dominik Seidel $^{1} \cdot$ Christian Ammer $^{1}$
}

Received: 31 October 2020 / Revised: 8 April 2021 / Accepted: 10 April 2021 / Published online: 26 April 2021

(c) The Author(s) 2021

\begin{abstract}
Research on mixed forests has mostly focused on tree growth and productivity, or resistance and resilience in changing climate conditions, but only rarely on the effects of tree species mixing on timber quality. In particular, it is still unclear whether the numerous positive effects of mixed forests on productivity and stability come at the expense of timber quality. In this study, we used photographs of sawn boards from 90 European beech (Fagus sylvatica L.) trees of mixed and pure forest stands to analyze internal timber quality through the quality indicator knot surface that was quantitatively assessed using the software Datinf ${ }^{\circledR}$ Measure. We observed a decrease in knot surface with increasing distance from the pith as well as smaller values in the lower log sections. Regarding the influence of neighborhood species identity, we found only minor effects meaning that timber qualities in mixed stands of beech and Norway spruce (Picea abies (L.) H. Karst.) tended to be slightly worse compared to pure beech stands.
\end{abstract}

Keywords Deciduous timber $\cdot$ European beech $\cdot$ Forest conversion $\cdot$ Knottiness

\section{Introduction}

Throughout the twentieth century, forest management has perfected commercial timber production in forest stands consisting of only one tree species (Puettmann et al. 2012). As a result, even in areas that are naturally rich in tree species, a few species grown in monocultures dominate the picture (Bauhus et al. 2017a, b). This development was driven by simpler planning, easy silvicultural operations, and the high predictability of the (wooden) products obtained by even-aged monospecific forest management (Bauhus et al. 2017a). However, in the past two decades there has been an increased focus on exploring advantages and disadvantages of mixing species regarding productivity and timber quality

Communicated by Martina Meincken.

Kirsten Höwler

kirsten.hoewler@forst.uni-goettingen.de

1 Silviculture and Forest Ecology of the Temperate Zones, Faculty of Forest Sciences, University of Göttingen, Büsgenweg 1, 37077 Göttingen, Germany

2 Forest and Agroforest Systems, Technical University of Munich (TUM), Hans-Carl-von-Carlowitz-Platz 2, 85354 Freising, Germany in commercial forests, as well as operational challenges (Knoke et al. 2008; Bauhus et al. 2017a; Bravo-Oviedo et al. 2018; Messier et al. 2019). Monospecific stands are, with a few exceptions (see Hobi et al. 2015), rare in natural forests and thus are mostly a sign of anthropogenic activities. Such monospecific stands also seem to be more susceptible to abiotic and biotic stressors (Bauhus et al. 2017a). Nowadays, silvicultural activities are aiming at creating more diverse and more structured forest stands across Europe. As a result, the proportion of single-species forest stands has steadily decreased due to forest conversion in favor of more heterogeneous mixed forest stands (FAO 2001; von Lüpke et al. 2004; Forest Europe 2015; Pach et al. 2018). Many European countries started to convert pure coniferous forests into mixed and deciduous forests a few decades ago and this conversion is currently still ongoing due to changed forest policies (von Lüpke et al. 2004; Ammer et al. 2008; Forest Europe 2015). Mixed forest stands are considered to promote biological and structural diversity (Knoke et al. 2008; Bauhus et al. 2017a; Ampoorter et al. 2020), can enhance productivity (e.g., Vilà et al. 2007; Pretzsch and Schütze 2009; Paquette and Messier 2011; Pretzsch et al. 2015; Ammer 2019), and offer greater ecological and economic stability and resilience under changing and uncertain future climate conditions (von Lüpke et al. 2004; Millar et al. 2007; 
Knoke et al. 2008; Knoke and Seifert 2008). While the knowledge on growth, nutrient cycling, and other ecosystem functions of mixed forests has strongly improved, much less is known about timber quality, i.e., whether the mentioned advantages of mixed forests come at the expense of timber quality. In particular, with regard to upcoming changes on the timber market (e.g., higher availability of deciduous trees and lower availability of coniferous trees; e.g., Dill-Langer and Aicher 2014; Orazio et al. 2017), mixed neighborhood effects on deciduous timber quality (e.g., for European beech) need to be investigated more intensely. Currently, only about half of the sustainable annual growth production and thus wood utilization potential of several deciduous tree species is being harvested and used (Lorenz et al. 2018). In Europe, out of approximately 800 million $\mathrm{m}^{3}$ of roundwood in 2018, coniferous roundwood accounted for around $71 \%$ (calculated from FAOSTAT data; FAO 2020). Industrial roundwood (coniferous and deciduous) accounted for about $80 \%$ and wood fuel (coniferous and deciduous) for about $20 \%$ of the total roundwood. However, the shares of coniferous and deciduous timber vary considerably: While approximately $80 \%$ of coniferous timber is used for industrial roundwood, about $62 \%$ of deciduous timber is used as wood fuel (calculated from FAOSTAT data; FAO 2020). This means that only a small amount of the harvested deciduous timber is used for high-quality material in the first processing stage. These differences in timber usage are not primarily a result of supply but of processing capabilities (Ammann et al. 2016; Konnerth et al. 2016; Aicher et al. 2018), consumers preferences (Gartner 2005; Knoke et al. 2006) and different wood properties (Spellmann 2005). Coniferous and deciduous timber differ in anatomical structure and complexity (e.g., Matyssek et al. 2010). This results in different physical, mechanical, and chemical properties observed in hardwood when compared to coniferous timber. All these factors may explain why a substitution of coniferous timber by deciduous timber is currently underexplored and underrepresented (Schier et al. 2018). So, developing an understanding of where the potential for substitution exists and which factors influence deciduous timber quality is of crucial importance. It seems neither ecologically nor economically sustainable to use such a high proportion of potentially valuable timber for energy purposes only (DillLanger and Aicher 2014).

In general, the timber quality of a stem is affected by the tree's neighborhood and resulting competition (Höwler et al. 2017; Burkardt et al. 2019). With an increasing species diversity in mixed forest stands, the diversity of the competitive environment also increases and with this, the potential effects on timber quality. On the one hand, mixed forest stands are of higher structural heterogeneity compared to monospecific forest stands (Juchheim et al. 2019). This may increase the variability in stem and crown form, stem taper, stem bending or straightness, number of branches and branch dimensions, or the range of wood properties in general, all leading to changed timber quality (Bayer et al. 2013; Pretzsch and Rais 2016; Bauhus et al. 2017b; Benneter et al. 2018). On the other hand, admixed tree species may also serve as trainer trees to foster self-pruning of the lower and most valuable stem section on crop trees and consequently improve timber quality (Bauhus et al. 2017b). Moreover, timber quality is also influenced by the silvicultural treatments applied during the whole rotation cycle such as for example pruning, pre-commercial, and commercial thinning. In summary, the effect of mixed-species neighborhoods on the timber quality of a target tree can be expected to depend on species interactions, competitive capacity, species composition, and silvicultural regime or treatment (Bauhus et al. 2017b; Benneter et al. 2018). One of the most important features for timber quality is the amount, condition, and size of knots. According to European grading standards, a single knot could downgrade an entire log (Deutsches Institut für Normung e. V. 2011; Deutsches Institut für Normung e. V. 2013) due to its effects on mechanical, physical, and aesthetic properties of timber (Torkaman et al. 2018). Because of discontinuities and deviations in anatomical structure, knots cause a reduction in strength and stiffness as well as changes in swelling and shrinking behavior of timber (Osborne and Maguire 2016; Richter 2019). To a certain degree, silvicultural management can be applied to control the amount, condition, and size of branches. For example, branch size and self-pruning can be influenced by maintaining high densities in early stand development phases (e.g., Hein 2008). After this 'qualification phase', accelerated diameter increment can be fostered by crown release (e.g., Hein 2008). As small branches are more rapidly occluded compared to large branches, the resulting knotty core inside the log is also smaller (O'Hara 2007; Kint et al. 2010). Forest management therefore often seeks to minimize the branch diameter and branch occlusion period (Hein 2008). This study aims at expanding the understanding of mixed forest dynamics by focusing on timber quality in mixtures. We evaluated and compared tree logs from mixed and pure stands for one of the most important Central European tree species (Knoke 2003), European beech (Fagus sylvatica L.). Our primary research questions were:

1. How is the timber quality attribute knot surface distributed along the horizontal and vertical stem axis of European beech trees?

2. How does neighborhood species identity affect the timber quality attribute knot surface of European beech trees?

We hypothesized that (i) the timber quality attribute knot surface increases along the vertical stem axis (from bottom 
to top) and decreases along the horizontal stem axis (from pith to bark) as a result of the applied silvicultural treatment. We further hypothesized that (ii) the timber quality attribute knot surface is smaller in pure compared to mixed beech stands due to higher competition intensity of beech itself. For simplicity, we have used the term 'timber quality' in this study to refer to all negative and positive internal and external stem, wood or timber properties.

\section{Methods}

The horizontal and vertical distribution of the timber quality attribute knot surface (cf. Eq. 1) and the effect of the identity of neighboring tree species on timber quality of European beech were investigated using 90 European beech sample trees from four forest mixture types (Table 1). The criteria for the selection of sample trees were (i) tree classes 1-3 (dominant to co-dominant) according to Kraft (1884) and (ii) a diameter at breast height (DBH, at $1.3 \mathrm{~m}$ ) between 35 and $50 \mathrm{~cm}$. Additionally, these beech sample trees (iii) had at least two major (dominant or co-dominant) competitors either from the same species (pure beech stands) or from the admixed tree species (mixed beech stands). Whether a neighboring tree was classified as a major competitor depended on its size compared to the size of the target tree (Tomé and Burkhart 1989): all neighboring trees with a similar or larger DBH and a similar tree height were therefore classified as main competitors.

All sample trees were harvested during a commercial harvest of the forest district Reinhausen (Niedersächsische Landesforsten, Germany). Subsequently, the trees were sawn into $180 \mathrm{log}$ sections of differing length ( $\min .3 \mathrm{~m}$, max. $5 \mathrm{~m}$ ) and eventually to 1900 boards of differing thickness (min. $20 \mathrm{~mm}$, max. $50 \mathrm{~mm}$ ) according to the standard commercial sawing procedure of the cooperating sawmill (Fehrensen $\mathrm{GmbH}$, private limited company, Hann. Münden, Germany; cf. Table 2). For this study, we analyzed the boards of the first two log Sects. (6-10 m height in total) of each sample tree, as the first $10 \mathrm{~m}$ account for approximately $80 \%$ of the deciduous timber value (Bachmann 1970; Kint et al. 2010).

Each board was photographed lengthwise using a singlelens reflex camera (Pentax K10D), which was mounted on a tripod. This ensured that each photograph was taken at the same angle $\left(90^{\circ}\right)$ and the same distance $(1 \mathrm{~m})$ to the board (Fig. 1).

The number of photographs taken per board varied between three and five due to differences in total lengths of the boards. Therefore, all photographs of each individual board were manually merged using the software CorelDRAW @ X4 (version 14.0.0.567, Corel Corporation 2008). Subsequently, a quantitative timber quality measurement was conducted using the software Datinf ${ }^{\circledR}$ Measure (version 2.2, Datinf GmbH, Tübingen, Germany). Datinf® Measure is a software to measure surfaces or lengths on, e.g., photographs and uses vector-based measuring tools. For a successful measurement, a scale that was provided through a measuring tape on every photograph enabled the conversion of pixel into metric units. Then, the 'distance' tool of the software was applied to measure the board length as well as the board width (assessed every $50 \mathrm{~cm}$ ). Correspondingly, all surfaces were assessed using the 'polygon' tool of the software (Fig. 2). This included the total board surface (without bark), but also the quality attribute knot surface, which is considered an indicator of knottiness (Höwler et al. 2019). The position on the measuring tape was assigned to each measured object to obtain information about the height above the forest floor (see Höwler et al. 2019 for further methodological details).

The logs were virtually divided into (i) board groups according to the distance to the central board to analyze the distribution of quality attributes along the horizontal stem axis for the lower (upper end at $\min .3 \mathrm{~m}$, max. $5 \mathrm{~m}$ height) and upper (upper end at min. $6 \mathrm{~m}$, max. $10 \mathrm{~m}$ height) $\log$ sections and into (ii) height strata of $50 \mathrm{~cm}$ to investigate the distribution of quality attributes along the vertical stem axis (see Fig. 3).

\section{Horizontal distribution of knot surface}

The horizontal distribution of the timber quality attribute knot surface from pith to bark was analyzed separately for the lower (3-5 m height) and upper log Sects. (6-10 m height), because the number of boards was higher for the lower sections due to stem taper. The number of boards per $\log$ section was determined for each sample tree (lower log sections: min. 6 boards, max. 17 boards; upper log sections: min. 6 boards, max. 15 boards) to define the central board as a measure of pith within the log sections. If there was an uneven number of boards within a log section, the median board was marked as the central board. If there was an even number of boards, the central board was calculated using the mean of the two middle boards of the log section. A number was assigned to each board to group them by distance to the central board, starting from the central board (group 0). The number for a particular group of boards was multiplied by the board thickness ( $\min .21 \mathrm{~mm}$, max. $50 \mathrm{~mm}$ ) to calculate the distance of the boards from the determined center of the logs. Offcuts were excluded from this study so that the maximum radius of the logs was $200 \mathrm{~mm}$.

\section{Vertical distribution of knot surface}

The lower (3-5 m height) and upper (6-10 m height) log sections of each sample tree were merged to investigate the vertical distribution of the timber quality attribute knot 


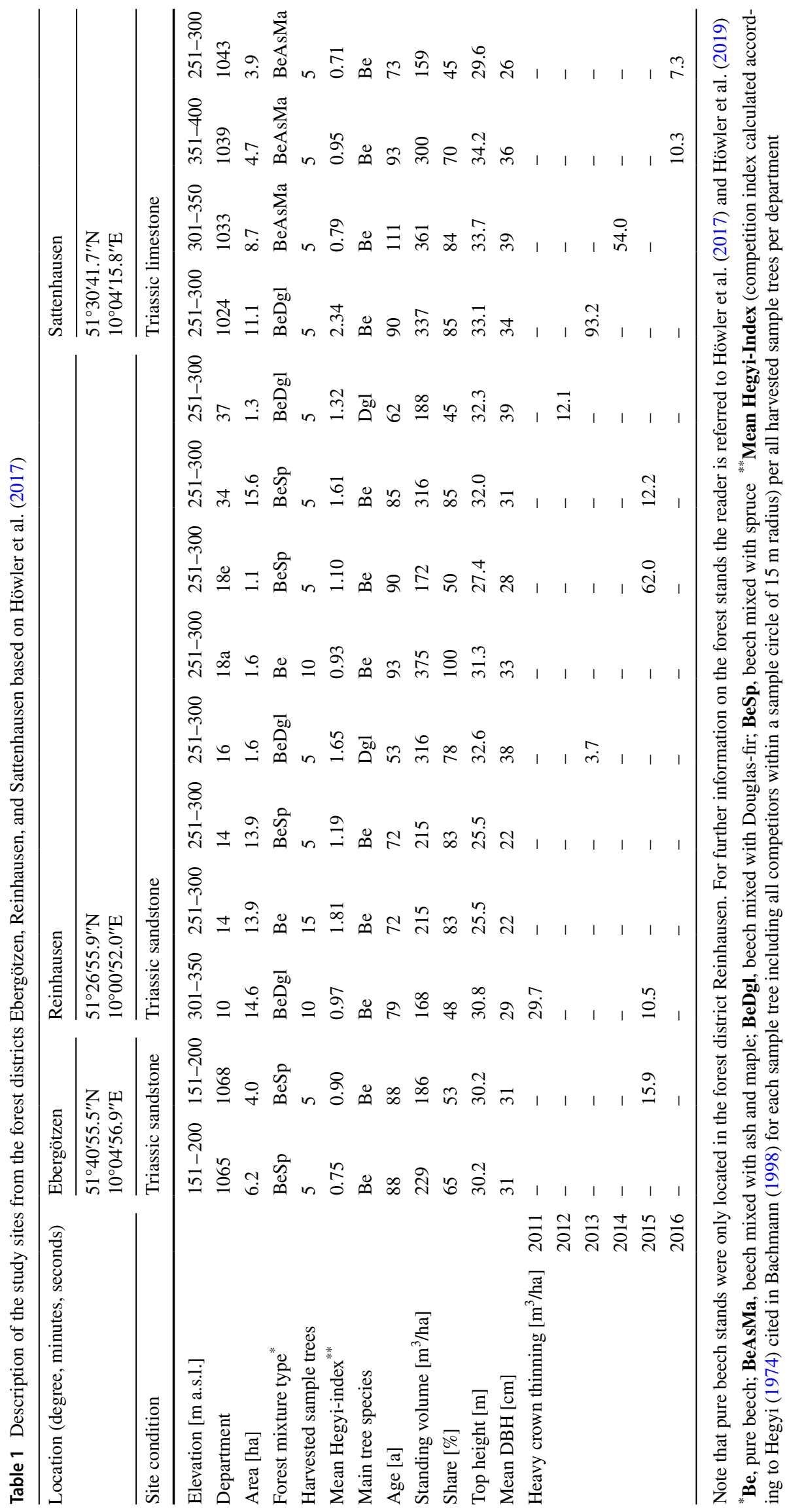


Table 2 Description of the investigated sample tree material from four forest mixture types: mixed European beech stands with Norway spruce, with ash and maple, with Douglas-fir, and pure European beech stands

\begin{tabular}{|c|c|c|c|c|c|c|c|c|}
\hline $\begin{array}{l}\text { Forest mix- } \\
\text { ture type }\end{array}$ & Tree species & $\begin{array}{l}\text { Age } \\
(\min -\max )\end{array}$ & $\begin{array}{l}\mathrm{DBH}[\mathrm{cm}] \\
(\mathrm{med} . \pm \mathrm{SD})\end{array}$ & $\begin{array}{l}n \\
\text { trees }\end{array}$ & $\begin{array}{l}n \log \\
\text { sections }\end{array}$ & $\begin{array}{l}n \\
\text { boards }\end{array}$ & $\begin{array}{l}n \text { height } \\
\text { strata } \\
(\min -\max )\end{array}$ & $\begin{array}{l}n \text { board } \\
\text { groups } \\
\text { (lower, upper) }\end{array}$ \\
\hline Pure & Fagus sylvatica $\mathrm{L}$ & $72-93$ & $41.1 \pm 4.4$ & 25 & 50 & 574 & $\begin{array}{l}14 \\
(0-650 \mathrm{~cm})\end{array}$ & 20,15 \\
\hline Mixed & $\begin{array}{l}\text { Fagus sylvatica L., } \\
\text { Picea abies (L.) H. Karst }\end{array}$ & $72-90$ & $42.6 \pm 6.1$ & 25 & 50 & 552 & $\begin{array}{l}20 \\
(0-950 \mathrm{~cm})\end{array}$ & 27,23 \\
\hline Mixed & $\begin{array}{l}\text { Fagus sylvatica L., } \\
\text { Pseudotsuga menziesii } \\
\quad \text { (Mirb.) Franco }\end{array}$ & $53-90$ & $37.7 \pm 6.9$ & 25 & 50 & 499 & $\begin{array}{l}20 \\
(0-950 \mathrm{~cm})\end{array}$ & 23,13 \\
\hline Mixed & $\begin{array}{l}\text { Fagus sylvatica } \mathrm{L} ., \\
\text { Acer platanoides } \mathrm{L} . / \\
\text { Acer pseudoplatanus L./ } \\
\text { Fraxinus excelsior } \mathrm{L}\end{array}$ & $73-111$ & $51.2 \pm 7.4$ & 15 & 30 & 275 & $\begin{array}{l}16 \\
(0-750 \mathrm{~cm})\end{array}$ & 14,11 \\
\hline
\end{tabular}

Listed are the main tree species, the minimum and maximum age as well as the median (med.) diameter at breast height (DBH) \pm standard deviation (SD) of the sample European beech trees, the number ( $n$ ) of sample trees, of log sections (LS), of analyzed boards, height strata (HS), and board groups (BG) for the lower and upper log sections

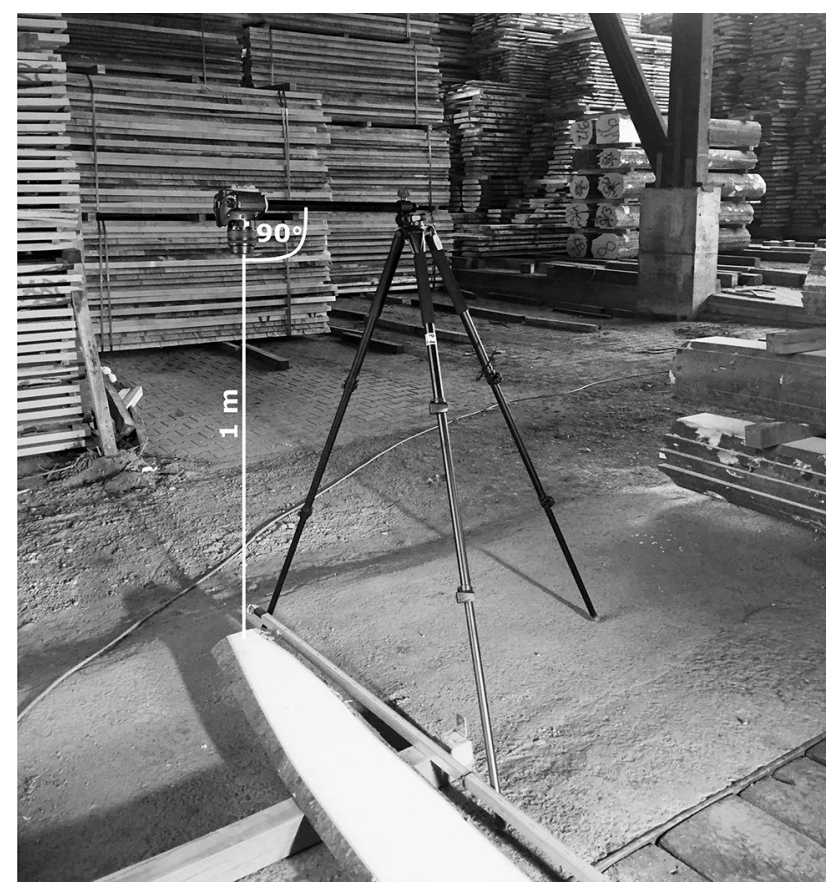

Fig. 1 Camera arrangement for the image acquisition at the Fehrensen $\mathrm{GmbH}$ showing the vertical distance to the board surface of $1 \mathrm{~m}$ and the angle to the board surface of $90^{\circ}$ (created using INKSCAPE version 0.92 and Adobe Photoshop CS3 Extended version 10.0; source Höwler et al. 2019)

surface from bottom to top (Fig. 3). These merged log sections were then divided into small height strata of $50 \mathrm{~cm}$ length, beginning with the first height strata at $0-50 \mathrm{~cm}$ (stump excluded) and ending with the last and maximum height strata at 950-1000 cm. During the internal timber quality assessment using Datinf® Measure, the height above the forest floor was assigned to all measured attributes providing the beginning and end of a quality attribute along the vertical axis. As some measured quality attributes covered more than one height strata, we calculated the proportions of each measured knot surface within each height strata using the total length, the beginning and ending values, as well as the total surface of a quality attribute. The knot surface per height strata was then calculated using Eq. 1:

knotsurface $_{0-50 \mathrm{~cm}}[\%]=\left(\frac{\sum_{i=1}^{n} \text { knotsurfaces }_{i_{0-50 \mathrm{~cm}}}\left[\mathrm{~cm}^{2}\right]}{\sum_{i=1}^{n} \text { boardsurfaces }_{i_{0-50 \mathrm{~cm}}}\left[\mathrm{~cm}^{2}\right]}\right) * 100$

Since the log sections varied in length (due to the commercial sawing procedure), we used relative heights. For this purpose, the maximum length of the log sections per sample tree was determined (e.g., two log sections of $3 \mathrm{~m}$, resulting in a maximum length of $6 \mathrm{~m}$ in total). This maximum length was set as $100 \%$, the $50 \mathrm{~cm}$ height strata were adjusted accordingly.

\section{Statistical analysis}

All statistical analyses were performed using the free and open-source-software R (version 4.0.4, R Core Team 2018) with a significance level set at $p<0.05$. The Shapiro-Wilk normality test was applied to test for normal distribution of the data.

\section{Horizontal distribution of knot surface}

The response variable knot surface was not normally distributed and we used arcsine transformation (y) for percentage 


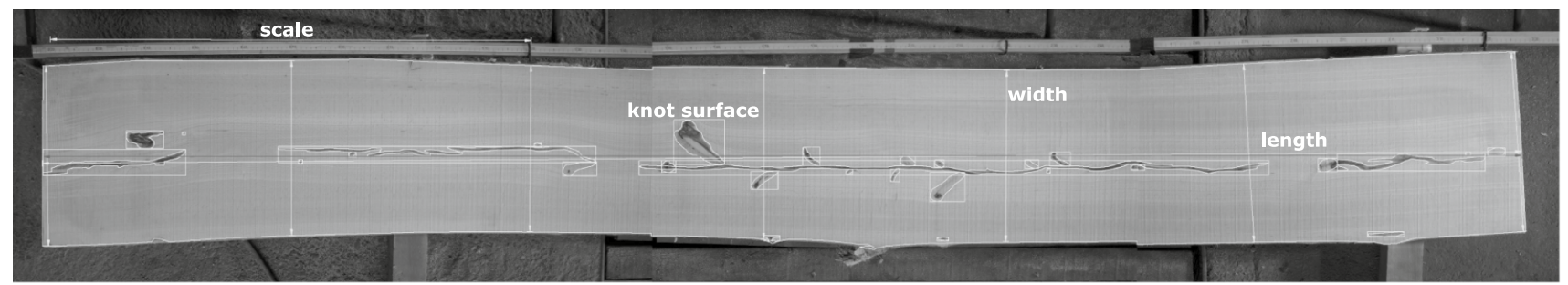

Fig. 2 Measurement of one board using the software Datinf® Measure including the total length, the widths assessed every $50 \mathrm{~cm}$, knot surfaces, and the total board surface. The scale on the measuring tape equaled $100 \mathrm{~cm}$ and enabled a transformation from pixel into metric units (created using IrfanView version 4.42 and Inkscape version $0.92)$

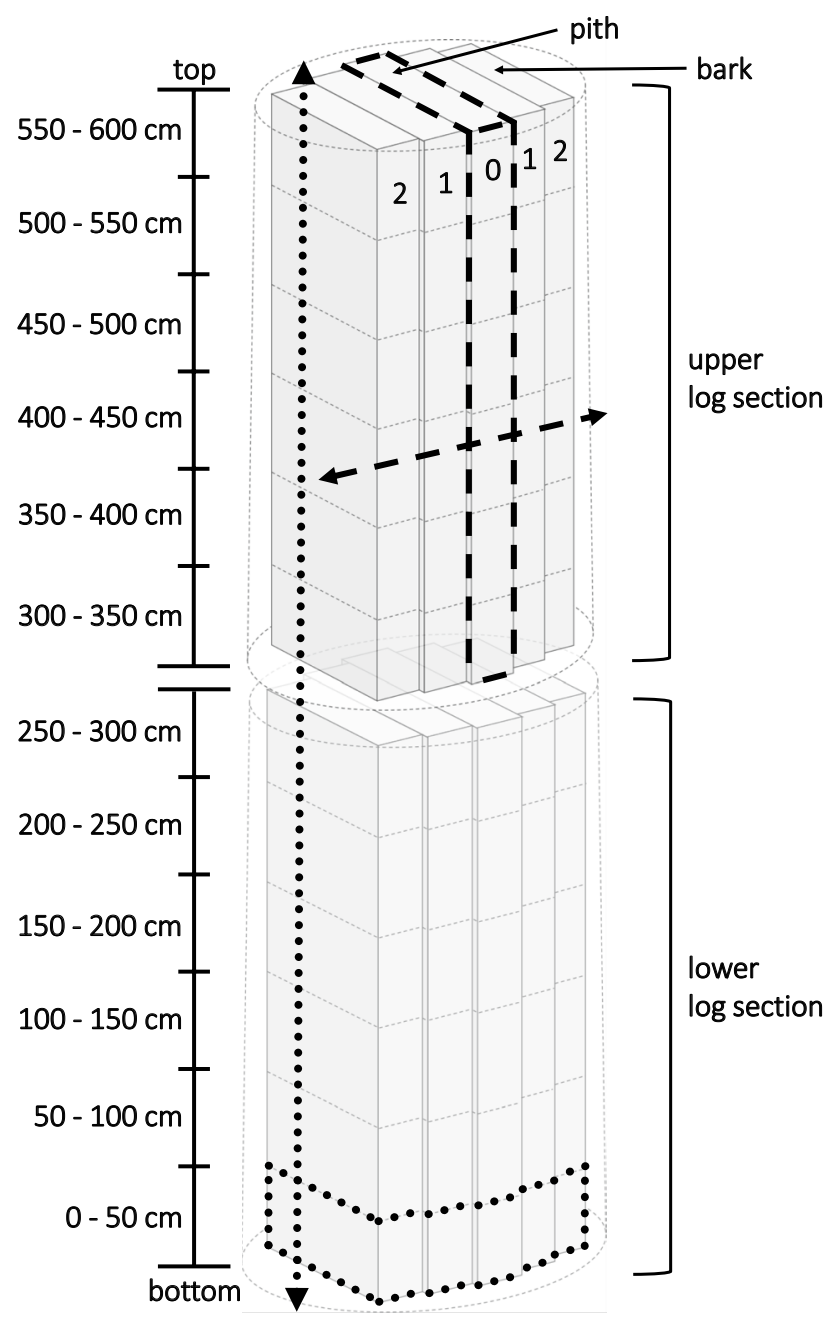

Fig. 3 Exemplary virtual composition of the boards of one European beech sample tree with two log sections of $3 \mathrm{~m}$ length each (lower log section: 0-300 cm, upper log section: 300-600 cm) and an unequal number of boards $(n=5)$. Shown are the central board (group 0 , equals the central board) and two subsequent board groups (group 1 and group 2, according to the distance from the central board) for the horizontal distribution of the timber quality attribute knot surface (dashed) as well as the height strata of $50 \mathrm{~cm}$ (starting with the first strata at $0-50 \mathrm{~cm}$, ending with the last strata at $550-600 \mathrm{~cm}$ ) for the vertical distribution of the timber quality attribute knot surface (dotted) data to linearize the relationship between the response and explanatory variables along the horizontal stem axis (Crawley 2012). The horizontal distribution of knot surface was analyzed for different forest mixture types using a linear mixed-effect model ('Imer' function of the package 'lme4'; Bates et al. 2015). In the linear mixed-effect model, 'distance to central board,' 'forest mixture type,' as well as interaction of 'distance to central board' and 'forest mixture type' were included as fixed effects. 'Tree ID' was set as random effect to account for correlation of boards of the same tree. To obtain $R^{2}$ from the linear mixed-effect model, we calculated marginal and conditional $R^{2}$. Marginal $R_{(\mathrm{m})}^{2}$ explains the proportion of variance by fixed effects and conditional $R_{(\text {c) }}^{2}$ the proportion of variance by both fixed and random effects (Nakagawa and Schielzeth 2013). The lower and upper log sections were analyzed separately, because the lower log sections contained more boards than the upper sections due to the natural taper of the trees.

\section{Vertical distribution of knot surface}

Since the assumptions for normal distribution were violated, generalized linear models (GLMs) were used to analyze the relationship between knot surface and the relative log height for different forest mixture types. The family of error structure was set to 'gamma' with an identity link function, as the quality attribute knot surface only had positive values.

\section{Results}

\section{Horizontal distribution of knot surface}

The linear mixed-effect model revealed a significant relationship between the quality attribute knot surface and distance to central board for the lower $\left(p<0.001, R^{2}{ }_{\mathrm{c}}=0.55\right.$; Table 3) and upper ( $p<0.001, R_{\mathrm{c}}^{2}=0.55$; Table 4) log sections. With increasing distance to the central board the knot surface decreased by $0.021 \% \mathrm{~mm}^{-1}$ for the lower (Table 3) and by $0.029 \% \mathrm{~mm}^{-1}$ for the upper log sections (Table 4 ). 
Table 3 Results of the linear mixed-effect model for the lower log Sects. (3-5 m) with knot surface (arcsine transformed) as response variable and distance to central board (distance) as explanatory variable

\begin{tabular}{lrllrlll}
\hline Fixed effects & Estimates & \multicolumn{1}{l}{$\mathrm{SE}$} & \multicolumn{1}{l}{ df } & $t$-value & $p$ value & $R_{(\mathrm{m})}^{2}$ & $R_{(\mathrm{c})}^{2}$ \\
\hline Intercept (Beech) & 3.769 & 0.286 & 148.855 & 13.189 & $<0.001$ & 0.28 & 0.55 \\
Distance & -0.021 & 0.002 & 860.000 & -9.529 & $<0.001$ & & \\
BeechDouglasfir & 0.515 & 0.407 & 152.661 & 1.266 & 0.207 & \\
BeechAshMaple & 0.233 & 0.486 & 158.908 & 0.479 & 0.632 & & \\
BeechSpruce & 1.310 & 0.403 & 147.181 & 3.251 & 0.001 & \\
Distance: BeechDouglasfir & -0.005 & 0.005 & 863.444 & -1.432 & 0.152 & \\
Distance: BeechAshMaple & -0.001 & 0.004 & 862.210 & -0.344 & 0.731 & & \\
Distance: BeechSpruce & -0.012 & 0.003 & 864.700 & -3.994 & $<0.001$ & &
\end{tabular}

Given are the parameter estimates, standard error (SE), degrees of freedom (df), $t$-statistics ( $t$-value), model significance ( $p$ value), marginal $R^{2}\left(R_{(\mathrm{m})}^{2}\right)$ and conditional $R^{2}\left(R_{(\mathrm{c})}^{2}\right)$

\begin{tabular}{lccrrrrr}
\hline Fixed effects & Estimates & \multicolumn{1}{l}{$\mathrm{SE}$} & \multicolumn{1}{c}{$\mathrm{df}$} & \multicolumn{1}{l}{$t$-value } & $p$ value & $R_{(\mathrm{m})}^{2}$ & $R_{(\mathrm{c})}^{2}$ \\
\hline Intercept (Beech) & 5.035 & 0.550 & 67.277 & 9.168 & $<0.001$ & 0.20 & 0.55 \\
Distance & -0.029 & 0.005 & 334.828 & -5.713 & $<0.001$ & & \\
BeechDouglasfir & -0.260 & 0.752 & 68.657 & -0.345 & 0.731 & \\
BeechAshMaple & 0.477 & 1.127 & 73.871 & 0.423 & 0.674 & \\
BeechSpruce & 1.477 & 0.757 & 65.789 & 1.950 & 0.055 & \\
Distance: BeechDouglasfir & 0.006 & 0.008 & 337.332 & 0.791 & 0.430 & \\
Distance: BeechAshMaple & 0.004 & 0.009 & 337.205 & 0.387 & 0.699 & \\
Distance: BeechSpruce & -0.010 & 0.007 & 337.889 & -1.536 & 0.125 & & \\
\hline
\end{tabular}

Given are the parameter estimates, standard error (SE), degrees of freedom (df), $t$-statistics ( $t$-value), model significance ( $p$ value), marginal $R^{2}\left(R_{(\mathrm{m})}^{2}\right)$ and conditional $R^{2}\left(R_{(\mathrm{c})}^{2}\right)$
Table 4 Results of the linear mixed-effect model for the upper $\log$ Sects. $(6-10 \mathrm{~m})$ with knot surface (arcsine transformed) as response variable and distance to central board (distance) as explanatory variable with ash and maple no significant relationship between the knot surface and distance to the central board was observed. The linear mixed-effect model was therefore reduced by merging 'pure beech stand' with the mixture types 'beech with ash and maple' as well as 'beech with Douglas-fir.' The merged group was tested against the mixture type 'beech with spruce.' We found that internal boards (distance to central board $=0 \mathrm{~mm}$ ) of beech mixed with spruce had larger knot surfaces that decreased more steeply with increasing distance to the central board compared to the grouped forest mixture types (Fig. 5). For the upper log sections, there was no significant difference $(p<0.05)$ between the forest mixture types (Table 4).

\section{Vertical distribution of knot surface}

The GLM analysis revealed a significant positive relationship between knot surface and relative log height $\left(p<0.001, R_{\text {pseudo }}^{2}=0.043\right)$ for European beech trees from pure beech stands, from mixed stands with Douglas-fir, or from mixed stands with Norway spruce (Table 5). With increasing relative log height, the quality attribute knot surface increased $(0.004 \pm 0.001 \%$ knot surface $)$; however this relationship was very weak. At stem basis $(0 \%$ relative $\log$ height, Fig. 6), beech trees from mixture with Norway 

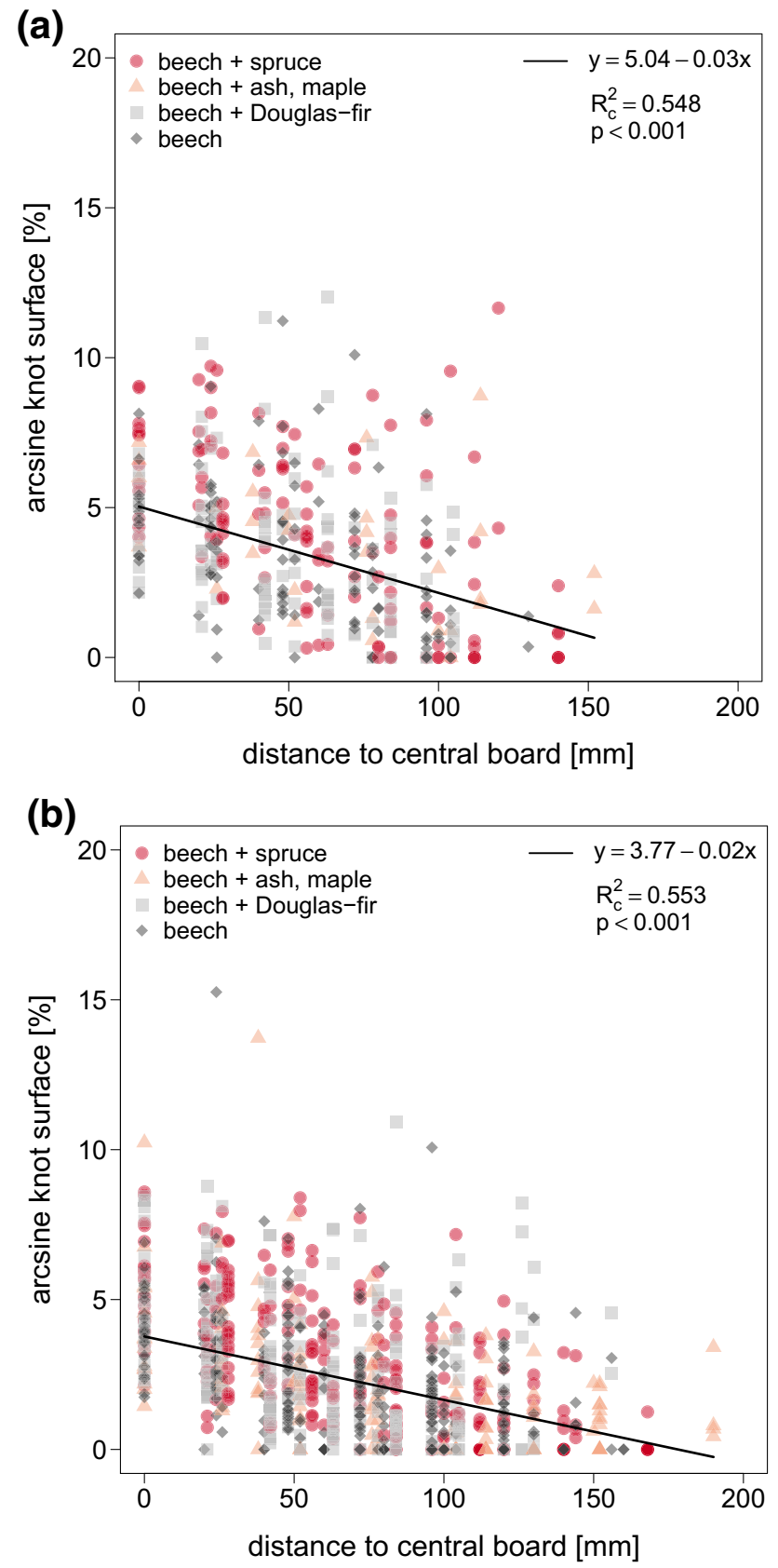

Fig. 4 Relationship between arcsine knot surface [\%] and distance to the central board $[\mathrm{mm}]$ for a the lower log Sects. (3-5 m height) and b the upper log Sects. (6-10 m height) of European beech trees from mixed forest stands with Norway spruce, with ash and maple, with Douglas-fir, and from pure beech stands. The lines refer to the applied linear mixed-effects models. Significant relationships at $p<0.05$ are presented

spruce had the largest knot surfaces $(0.32 \pm 0.043 \%)$, followed by beech trees from mixture with Douglas-fir $(0.28 \pm 0.041 \%)$. Smallest knot surfaces at $0 \%$ relative log height were found for European beech trees from pure

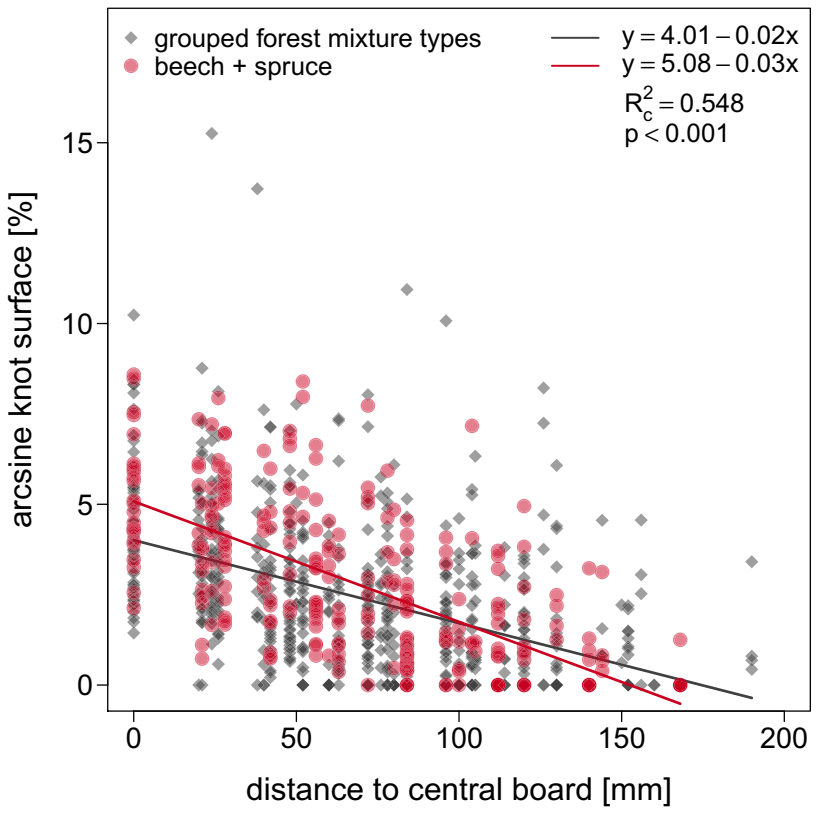

Fig. 5 Relationship between arcsine knot surface [\%] and distance to the central board $[\mathrm{mm}]$ for the lower log Sects. (3-5 $\mathrm{m}$ height) of European beech trees from mixed forest stands with Norway spruce, with ash and maple, with Douglas-fir, and from pure beech stands. The forest mixture types 'pure beech,' 'beech mixed with ash and maple' as well as 'beech mixed with Douglas-fir' were merged and are displayed in gray rhomb. The lines refer to the applied reduced linear mixed-effects model. Significant relationships at $p<0.05$ are presented

beech stands $(0.198 \pm 0.03 \%)$. In a similar way to the distribution of knot surface along the horizontal stem axis, the knot surface along the vertical axis was at most 9\%.

Over the entire relative log height $(0-100 \%)$, beech trees from mixture with spruce showed the largest knot surface, followed by beech trees from mixture with Douglas-fir. Beech trees from pure stands showed the smallest knot surface (Fig. 6). When mixed with ash and maple the relationship was not significant. Expressed in absolute values, 100\% relative log height (in relation to the maximum length of the analyzed tree) of the 90 European beech sample trees ranged from $6.14 \mathrm{~m}$ (average pure beech stands) to $6.96 \mathrm{~m}$ (average mixed stands with spruce).

\section{Discussion}

\section{Question 1: How is the timber quality attribute knot surface distributed along the horizontal and vertical stem axis of European beech trees?}

The lower log sections (up to approximately $10 \mathrm{~m}$ height) of deciduous trees are usually economically most valuable and can contain up to $80 \%$ of the timber value (Bachmann 
Table 5 Results of the generalized linear model to describe the relationship between the response variable knot surface [\%] dependent on the explanatory variables relative log height [\%] as well as forest mixture type

\begin{tabular}{llrrrrr}
\hline Quality attribute & Model parameter & Estimate & SE & $t$-value & $p$ value & $R_{\text {pseudo }}^{2}$ \\
\hline Knot surface & Relative log height & 0.004 & 0.001 & 7.166 & $<0.001$ & 0.043 \\
& Beech & 0.198 & 0.030 & 6.679 & $<0.001$ & \\
& Beech + Douglas-fir & 0.082 & 0.041 & 2.020 & 0.044 & \\
& Beech + ash, maple & -0.059 & 0.037 & -1.625 & 0.104 & \\
& Beech + spruce & 0.126 & 0.043 & 2.945 & 0.003 & \\
\hline
\end{tabular}

Given are the model parameter estimates (estimate) with their standard errors (SE), t-statistics ( $t$-value), model significance ( $p$ value), and pseudo R squared $\left(R_{\text {pseudo }}^{2}\right)$

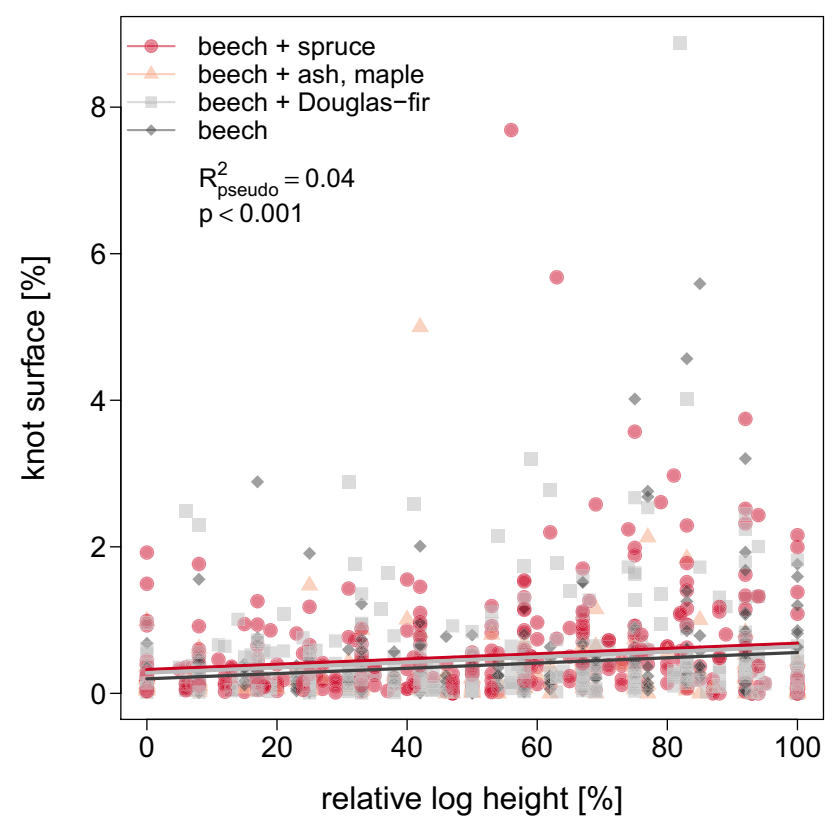

Fig. 6 Relationship between relative log height [\%] and knot surface [\%] of European beech trees from mixed forest stands with Norway spruce, with ash and maple, with Douglas-fir, and from pure beech stands. The lines refer to the applied generalized linear models with gamma family distribution. Only significant relationships at $p<0.05$ are presented

1970; Kint et al. 2010). The timber value of a tree is related to the branch characteristics and the self-pruning of trees at younger ages (Kint et al. 2010). Thus, as the initial part of branches will be encased within the stem, the position and the extent of these branches are of great importance for timber quality (e.g., European standard EN 1316-1:2012; Deutsches Institut für Normung e. V. 2013). The most important silvicultural tool to influence branchiness in close-to-nature forestry is to control competition by managing stand density through thinning. Once the desired degree of self-pruning has been achieved, a phase of crown release is usually initiated in order to promote diameter growth of a now branch-free valuable lower stem (e.g., Hein 2008; Pretzsch 2019). The higher branchiness and branch dimensions on the upper log sections are tolerated, as high stem volume increment is intended. This practice was reflected in our study since the knot surfaces significantly increased with increasing relative log height (even though the relationship was rather weak). As the diameter increases, the proportion of branch-free wood on the log also increases outwardly in horizontal direction. This holds true for the investigated European beech trees studied here since knot surface significantly decreased along the horizontal stem axis with larger knot surface on boards close to the determined center of the logs. In summary, timber quality increased along the horizontal stem axis and decreased along the vertical stem axis with highest timber quality for the outer parts of the lower log sections of the investigated European beech trees. The results imply that the silvicultural treatments applied up to the day of harvest have effectively reduced knottiness in the lower and most important stem sections as well as in the outer boards of the logs. This supports hypothesis (i) stating that 'the timber quality attribute knot surface increases along the horizontal stem axis and decreases along the vertical stem axis as a result of the applied silvicultural treatment.' Obviously, the effect of a quite homogeneous silvicultural treatment (heavy thinning from above) in all kinds of investigated stands was stronger than the species identity effect. This view is supported by rather similar mean competition indices (cf. Table 1). Unfortunately, no information was available for the timber quality of European beech trees from unmanaged stands and thus stronger competitive pressure.

\section{Question 2: How does neighborhood species identity affect the timber quality attribute knot surface of European beech trees?}

We hypothesized higher timber quality of European beech trees from pure compared to mixed forest stands due to the higher intraspecific competitive pressure of European beech (Dieler 2011; Metz et al. 2013; Bauhus et al. 2017b). High intraspecific competitive pressure should lead to higher selfpruning and reduced knottiness. Since we observed higher timber quality in terms of smaller knot surface in pure beech stands compared to mixed beech stands with Norway spruce, our results support hypothesis (ii) that the timber quality attribute knot surface is smaller in pure compared 
to mixed beech stands due to higher intraspecific competition. This finding is in accordance with, e.g., Pretzsch and Rais (2016) who reviewed more than 100 publications on the morphology of mixed versus pure forest stands and deduced decreased timber quality in mixed forest stands (due to more heterogeneous growing conditions) from these publications. Their review focused on wood properties relevant for construction wood (e.g., knots, density). In our study, the smallest values for knot surface were found in sample trees from pure beech forest stands and largest in mixture with Norway spruce. This result might be attributable to a complementary light ecology of European beech and Norway spruce. Spruce crowns are cone-shaped, comparably narrow and triangular, whereas beech crowns are a cubical paraboloid (Pretzsch 2019). In mixture with Norway spruce, beech shows a greater horizontal and vertical crown expansion (Pretzsch and Rais 2016; Barbeito et al. 2017), which can result in vertically layered canopies (Pretzsch 2014) as well as in a shift of the crown towards a deeper stem section (Pretzsch and Rais 2016; Barbeito et al. 2017). The reason for this is seen in a more heterogeneous horizontal and vertical structure, which allows more light to reach lower canopy layers in mixed forest stands leading to delayed crownuplifting (Pretzsch and Rais 2016), consequently leading to a delay in self-pruning compared to pure beech stands (cf. Bayer et al. 2013) and a higher knot surface. In contrast to mixtures with Norway spruce, no significant effect of neighborhood species identity was observed for beech trees mixed with Douglas-fir (along the horizontal stem axis and a rather weak relationship was found along the vertical stem axis). Initially, we had expected similar effects of the two conifers on beech timber quality. However, it may be that Douglas-fir, a species with higher growth rates than Norway spruce, have exerted stronger competition to beech than Norway spruce (Schütz and Pommerening 2013). Thus, we assume that Douglas-fir, which has found to be able to even outcompete beech (Bartelink 2000), resembled more the intraspecific competition of beech than the interspecific interference by spruce. In pure forest stands, trees occupy the same ecological niche with high intraspecific competitive pressure, whereas in mixed forest stands complementary effects can be observed resulting in reduced competition (Ammer 2017; 2019). Beech exposes highest intraspecific competition (Dieler 2011; Metz et al. 2013) and sample trees might thus have benefited from the lowered competition in mixture with spruce and expanded their crowns, which led to higher branch diameters and correspondingly higher knottiness. This could explain the observed larger knot surface (less natural pruning) in mixed forest stands with Norway spruce. Not only the total knot surface was larger in mixture with spruce, but also the central boards were knottier. This is due to less intense competition even from a young stand age and a lower stand density in coniferous-deciduous mixtures (compared to monospecific stands) caused by ecological niche complementarity. This is consistent with the fact that the smallest values of knot surface along the vertical stem axis were observed in pure beech stands and the largest values in mixture with Norway spruce. Neighborhood density and thus competition intensity seemed to be very important for controlling timber properties and might outweigh possible mixing effects.

A methodological shortcoming of our study was that the investigated forest stands are commercially managed and have undergone a history of thinning measures. The majority of the sample trees was classified as quality grade B or C (good and medium quality according to German quality grading guidelines, RVR 2014) and none of the investigated sample trees were classified in grade A (best quality) or grade D (bad quality). Nevertheless, an earlier study could show that this visual external quality grading (RVR 2014) of the sample trees conducted by local foresters was in compliance with internal timber quality attributes (Höwler et al. 2019). For these reasons, we support hypothesis (ii) that timber quality (in terms of knot surface) is higher in pure beech stands compared to mixed beech stands with conifer tree species such as Norway spruce. Since the proportion of beech trees within the mixed forest stands was also rather high, we cannot exclude intraspecific competition to a certain degree even there. This indicates that the observed (small) differences between pure and mixed forest stands might be even more pronounced in solely interspecific neighborhoods (cf. share of main tree species in Table 1) and highlights the importance of continuing to study the effect of neighborhood species identity on timber quality in mixed forest stands.

\section{Conclusion}

Even though comparatively good timber quality grades and a consistently rather small knot surface were found for European beech trees in mixed stands, we were able to detect significant differences between the stand types-even though they were small. The results showed that for European beech the knot surface on the horizontal and vertical stem axis appears to be affected differently depending on the neighboring species, which implicitly means that it can be controlled through silvicultural measures. Thus, although mixed forest stands are advantageous in several respects, the possibility of lower timber qualities (for European beech) should be taken into account for future forestry scenarios calculating with lager proportions of mixed stands. However, we only investigated the timber quality of European beech and have no information on the qualities of the admixed tree species that might compensate a 'quality loss' of beech timber. Moreover, for the investigated European beech trees, 
the differences between the stand types were small, did not change the timber value and are of low impact for the timber industry due to the small values for knot surface. Against this background, there is little to be said against but much to be said in favor of managing beech in mixed stands, since the actual outcome of timber quality seems to depend not only on the admixed tree species, but on stand management regime and hence forest structure, which was however not investigated here. Adequate silvicultural treatments in terms of stand density, competition control, tree species selection and distribution within forest stands could support the achievement of high-quality deciduous timber with reduced branchiness and knottiness even in mixed forest stands. To use the positive effects of intraspecific competition on beech timber quality on the one hand but promote mixed stands on the other hand, group-wise mixtures of tree species seem to be a promising concept. However, for features more dependent on the complementarity effect, single-species mixtures might still be the method of choice, highlighting that prioritization of management goals is essential for effective multifunctional silviculture.

Acknowledgements This work was supported by the Ministry for Science and Culture of Lower Saxony and conducted in the joint project 'Materialforschung Holz' (Reference Number 21.2-78904-63-3/14). We thank Axel Pampe and Wolf-Georg Fehrensen for providing the forest trees and supporting the sawing procedure. Furthermore, we thank the cooperating district foresters of the Forest Office of Reinhausen as well as the Fehrensen team for their support during field work. Special thanks go to Ulrike Westphal and Andreas Parth for assisting data collection and data management. We thank Hubert Merkel for helpful comments on an earlier version of this manuscript. Lastly, we would like to thank two reviewers whose comments have considerably improved the quality of this manuscript.

Funding Open Access funding enabled and organized by Projekt DEAL.

\section{Declarations}

Conflict of interest None declared.

Open Access This article is licensed under a Creative Commons Attribution 4.0 International License, which permits use, sharing, adaptation, distribution and reproduction in any medium or format, as long as you give appropriate credit to the original author(s) and the source, provide a link to the Creative Commons licence, and indicate if changes were made. The images or other third party material in this article are included in the article's Creative Commons licence, unless indicated otherwise in a credit line to the material. If material is not included in the article's Creative Commons licence and your intended use is not permitted by statutory regulation or exceeds the permitted use, you will need to obtain permission directly from the copyright holder. To view a copy of this licence, visit http://creativecommons.org/licenses/by/4.0/.

\section{References}

Aicher S, Ahmad Z, Hirsch M (2018) Bondline shear strength and wood failure of European and tropical hardwood glulams. Eur J Wood Prod 76:1205-1222

Ammann S, Schlegel S, Beyer M et al (2016) Quality assessment of glued ash wood for construction engineering. Eur J Wood Prod 74:67-74

Ammer C (2019) Diversity and forest productivity in a changing climate. New Phytol 221:50-66

Ammer C, Bickel E, Kölling C (2008) Converting Norway spruce stands with beech-a review of arguments and techniques. Austrian J For Sci 125:3-26

Ammer C (2017) Unraveling the importance of inter- and intraspecific competition for the adaption of forests to climate change. In: Canovas FM, Lüttge U, Matyssek R (eds) Progress in Botany. Springer, Cham, Switzerland, pp 345-367

Ampoorter E, Barbaro L, Jactel $\mathrm{H}$ et al (2020) Tree diversity is key for promoting the diversity and abundance of forest-associated taxa in Europe. Oikos 129:133-146

Bachmann P (1970) Wirtschaftliche Überlegungen zur Waldpflege. Hespa Mitteilungen 20:1-24

Bachmann M (1998) Indizes zur Erfassung der Konkurrenz von Einzelbäumen. Methodische Untersuchung in Bergmischwäldern, Frank, München

Barbeito I, Dassot M, Bayer D et al (2017) Terrestrial laser scanning reveals differences in crown structure of Fagus sylvatica in mixed vs. pure European forests. For Ecol Manage 405:381-390

Bartelink HH (2000) Effects of stand composition and thinning in mixed-species forests. A modeling approach applied to Douglasfir and beech. Tree Physiol 20:399-406

Bates D, Mächler M, Bolker B et al (2015) Fitting linear mixed effects models using lme. J Stat Soft. https://doi.org/10.18637/jss.v067. i01

Bauhus J, Forrester DI, Pretzsch H (2017a) Mixed-species forests: the development of a forest management paradigm. In: Pretzsch H, Forrester DI, Bauhus J (eds) Mixed-Species Forests. Springer, Berlin Heidelberg, Berlin, Heidelberg, pp 1-25

Bauhus J, Forrester DI, Pretzsch H et al (2017b) Silvicultural options for mixed-species stands. In: Pretzsch H, Forrester DI, Bauhus J (eds) Mixed-species forests. Springer, Berlin Heidelberg, Berlin, Heidelberg, pp 433-501

Bayer D, Seifert S, Pretzsch H (2013) Structural crown properties of Norway spruce (Picea abies [L.] Karst.) and European beech (Fagus sylvatica [L.]) in mixed versus pure stands revealed by terrestrial laser scanning. Trees 27:1035-1047

Benneter A, Forrester DI, Bouriaud O et al (2018) Tree species diversity does not compromise stem quality in major European forest types. For Ecol Manage 422:323-337

Bravo-Oviedo A, Pretzsch H, del Río M (eds) (2018) Dynamics silviculture and management of mixed forests. Springer International Publishing, Cham

Burkardt K, Annighöfer P, Seidel D et al (2019) Intraspecific competition affects crown and stem characteristics of non-native Quercus rubra L. Stands in Germany. Forests 10:846

Crawley MJ (2012) The R Book. Wiley

Deutsches Institut für Normung e. V. Schnittholz-Sortierung nach dem Aussehen von Laubholz-Teil 1: Eiche und Buche. Deutsche Fassung EN 975-1:2009 + AC:2010 79.040: 975-1:2011-08. Beuth Verlag GmbH, Berlin

Deutsches Institut für Normung e. V. Laub-Rundholz-Qualitäts-Sortierung-Teil 1: Eiche und Buche. Deutsche Fassung EN 13161:2012 79.040: 1316-1:2013-01. Beuth Verlag GmbH, Berlin

Dieler J (2011) Effekt von Mischung und Konkurrenz auf die Kronenmorphologie von Fichte (Picea abies [L.] Karst.) und Buche 
(Fagus sylvatica L.). Tagungsband der Sektion Ertragskunde im DVFFA, Cottbus:57-68

Dill-Langer G, Aicher S (2014) Glulam composed of glued laminated veneer lumber made of beech wood: superior performance in compression loading. In: Aicher S, Reinhardt H-W, Garrecht H (eds) Materials and joints in timber structures. Springer, Netherlands, Dordrecht, pp 603-613

FAO (2001) Global forest resources assessment 2000. Main Report. FAO Forestry Paper 140

FAO (2020) FAOSTAT Online Database. Forestry Production and Trade. http://www.fao.org/faostat/en/\#data/FO. Accessed $16 \mathrm{Apr}$ 2020

Forest Europe (2015) State of Europe's Forests 2015. https://www.fores teurope.org/docs/fullsoef2015.pdf. Accessed 14 Apr 2020

Gartner BL (2005) Assessing wood characteristics and wood quality in intensively managed plantations. J For 103:75-77

Hegyi F (1974) A simulation model for managing jack-pine stands. In: Fries J (Eds.) Growth Models for Tree and Stand Simulation: International Union of Forestry Research Organizations Working Party S4, Skogshögskolan, (pp 74-90)

Hein S (2008) Knot attributes and occlusion of naturally pruned branches of Fagus sylvatica. For Ecol Manage 256:2046-2057

Hobi ML, Commarmot B, Bugmann H (2015) Pattern and process in the largest primeval beech forest of Europe (Ukrainian Carpathians). J Veg Sci 26:323-336

Höwler K, Annighöfer P, Ammer C et al (2017) Competition improves quality-related external stem characteristics of Fagus sylvatica. Can J For Res 47:1603-1613

Höwler K, Vor T, Seidel D et al (2019) Analyzing effects of intra-and interspecific competition on timber quality attributes of Fagus sylvatica L.- - from quality assessments on standing trees to sawn boards. Eur J For Res 138:327-343

Juchheim J, Ehbrecht M, Schall P et al (2019) Effect of tree species mixing on stand structural complexity. Forestry 111:308

Kint V, Hein S, Campioli M et al (2010) Modelling self-pruning and branch attributes for young Quercus robur L. and Fagus sylvatica L. trees. For Ecol Manage 260:2023-2034

Knoke T (2003) Predicting red heartwood formation in beech trees (Fagus sylvatica L.). Ecol Model 169(2-3):295-312

Knoke T, Ammer C, Stimm B et al (2008) Admixing broadleaved to coniferous tree species. A review on yield, ecological stability and economics. Eur J For Res 127:89-101

Knoke T, Seifert T (2008) Integrating selected ecological effects of mixed European beech-Norway spruce stands in bioeconomic modelling. Ecol Modell 210:487-498

Knoke T, Stang S, Remler N et al (2006) Ranking the importance of quality variables for the price of high quality beech timber (Fagus sylvatica L.). Ann For Sci 63:399-413

Konnerth J, Kluge M, Schweizer G et al (2016) Survey of selected adhesive bonding properties of nine European softwood and hardwood species. Eur J Wood Prod 74:809-819

Kraft G (1884) Beiträge zur Lehre von den Durchforstungen. Verlag Klindworth, Hannover, Schlagstellungen und Lichtungshieben

Lorenz M, Englert H, Dieter M (2018) The German Forest Strategy 2020: target achievement control using National Forest Inventory results. Ann For Res 61:129-146

von Lüpke B, Ammer C, Braciamacchie M et al (2004) Silvicultural strategies for conversion. In: Spiecker H, Hansen J, Klimo E et al (eds) Norway spruce conversion-options and consequences. Leiden, Boston, Brill, pp 121-164

Matyssek R, Fromm J, Rennenberg H et al (2010) Biologie der Bäume. Von der Zelle zur globalen Ebene, 1st edn. Ulmer, Stuttgart (Hohenheim)

Messier C, Bauhus J, Doyon F et al (2019) The functional complex network approach to foster forest resilience to global changes. For Ecosyst. https://doi.org/10.1186/s40663-019-0166-2
Metz J, Seidel D, Schall P et al (2013) Crown modeling by terrestrial laser scanning as an approach to assess the effect of aboveground intra- and interspecific competition on tree growth. For Ecol Manage 310:275-288

Millar CI, Stephenson NL, Stephens SL (2007) Climate change and forests of the future: managing in the face of uncertainty. Ecol Appl 17:2145-2151

Nakagawa S, Schielzeth H (2013) A general and simple method for obtaining R2 from generalized linear mixed-effects models. Methods Ecol Evol 4:133-142

O’Hara KL (2007) Pruning wounds and occlusion: a long-standing conundrum in forestry. J For 105:131-138. https://academic.oup. $\mathrm{com} /$ jof/article/105/3/131/4598767? login=true

Orazio C, Kies U, Edwards D (2017) Handbook for wood mobilisation in Europe. Measures for increasing wood supply from sustainably managed forests, European Forest Institute

Osborne NL, Maguire DA (2016) Modeling knot geometry from branch angles in Douglas-fir (Pseudotsuga menziesii). Can J For Res 46:215-224

Pach M, Sansone D, Ponette Q et al (2018) Silviculture of mixed forests: a European overview of current practices and challenges. In: Bravo-Oviedo A, Pretzsch H, del Río M (eds) Dynamics, silviculture and management of mixed forests. Springer International Publishing, Cham, pp 185-253

Paquette A, Messier C (2011) The effect of biodiversity on tree productivity: from temperate to boreal forests. Glob Ecol Biogeogr 20:170-180

Pretzsch H (2014) Canopy space filling and tree crown morphology in mixed-species stands compared with monocultures. For Ecol Manage 327:251-264

Pretzsch H (2019) Grundlagen der Waldwachstumsforschung, 2nd edn. Springer Berlin Heidelberg

Pretzsch H, Rais A (2016) Wood quality in complex forests versus even-aged monocultures. Rev Perspect Wood Sci Technol 50:845-880

Pretzsch H, del Río M, Ammer C et al (2015) Growth and yield of mixed versus pure stands of Scots pine (Pinus sylvestris L.) and European beech (Fagus sylvatica L.) analysed along a productivity gradient through Europe. Eur J For Res 134:927-947

Pretzsch H, Schütze G (2009) Transgressive overyielding in mixed compared with pure stands of Norway spruce and European beech in Central Europe: evidence on stand level and explanation on individual tree level. Eur J For Res 128:183-204

Puettmann KJ, Coates KD, Messier CC (2012) A critique of silviculture: managing for complexity. Island press

R Core Team (2018) R: a language and environment for statistical computing. R Foundation for Statistical Computing, Vienna, Austria

RVR (2014) Rahmenvereinbarung für den Rohholzhandel in Deutschland (RVR). http://www.rvr-deutschland.de/docs/dynam isch/6205/rvr_gesamtdokument_2.auflage_stand_oktober_2015. pdf. Accessed 12 Apr 2017

Richter C (2019) Holzmerkmale der Bäume. Beschreibung der Merkmale-Ursachen-Vermeidung-Auswirkungen auf die Verwendung des Holzes-Technologische Anpassung, 1st edn. DRW-Verlag, Leinfelden-Echterdingen

Schier F, Morland C, Janzen N et al (2018) Impacts of changing coniferous and non-coniferous wood supply on forest product markets. A German scenario case study. Eur J For Res 137:279-300

Schütz JP, Pommerening A (2013) Can Douglas fir (Pseudotsuga menziesii (Mirb.) Franco) sustainably grow in complex forest structures? For Ecol Manage 303:175-183

Spellmann H (2005) Produziert der Waldbau am Markt vorbei? AFZ/ Der Wald 60:454-459

Tomé M, Burkhart HE (1989) Distance-dependent competition measures for predicting growth of individual trees. For Sci 35:816-831 
Torkaman J, Vaziri M, Sandberg D et al (2018) Relationship between branch-scar parameters and knot features of oriental beech (Fagus orientalis Libsky). Wood Mat Sci Eng 13:117-120

Vilà M, Vayreda J, Comas L et al (2007) Species richness and wood production: a positive association in Mediterranean forests. Ecol Lett 10:241-250
Publisher's Note Springer Nature remains neutral with regard to jurisdictional claims in published maps and institutional affiliations. 